\title{
Influence of Granular Activated Carbon on Anaerobic Co-Digestion of Sugar Beet Pulp and Distillers Grains with Solubles
}

\author{
Elvira E. Ziganshina, Dmitry E. Belostotskiy, Svetlana S. Bulynina and Ayrat M. Ziganshin * \\ Department of Microbiology, Institute of Fundamental Medicine and Biology, Kazan (Volga Region) Federal \\ University, 420008 Kazan, Russia; elvira.ziganshina@kpfu.ru (E.E.Z.); d.belostotskiy@gmail.com (D.E.B.); \\ SvSBulynina@stud.kpfu.ru (S.S.B.) \\ * Correspondence: ayrat.ziganshin@kpfu.ru; Tel.: +7-843-233-7881
}

Received: 20 August 2020; Accepted: 24 September 2020; Published: 1 October 2020

\begin{abstract}
Anaerobic digestion is an important technology to receive energy from various types of biomass. In this work, the impact of granular activated carbon (GAC) on the mesophilic anaerobic co-digestion of sugar beet pulp and distillers grains was investigated. After a short period, anaerobic reactors began to produce biomethane and were ready for completion within 19-24 days. The addition of GAC to reactors $\left(5-10 \mathrm{~g} \mathrm{~L}^{-1}\right)$ significantly enhanced the methane production rate and consumption of produced volatile fatty acids. Thus, the maximum methane production rate increased by $13.7 \%$ in the presence of GAC $\left(5 \mathrm{~g} \mathrm{~L}^{-1}\right)$. Bacterial and archaeal community structure and dynamics were investigated, based on $16 \mathrm{~S}$ rRNA genes analysis. The abundant classes of bacteria in GAC-free and GAC-containing reactors were Clostridia, Bacteroidia, Actinobacteria, and Synergistia. Methanogenic communities were mainly represented by the genera Methanosarcina, Methanoculleus, Methanothrix, and Methanomassiliicoccus in GAC-free and GAC-containing reactors. Our results indicate that the addition of granular activated carbon at appropriate dosages has a positive effect on anaerobic co-digestion of by-products of the processing of sugar beet and ethanol distillation process.
\end{abstract}

Keywords: anaerobic co-digestion; biomethane; sugar beet pulp; distillers grains; granular activated carbon; 16S rRNA gene

\section{Introduction}

Anaerobic digestion is an important technology to receive energy from organic wastes in the form of energy-rich biogas, whilst the digestate can be further used as bio-fertilizer. However, the anaerobic digestion process of distinct substances, although it is environmentally friendly, is quite sensitive to several disturbances and, in many cases, leads to a low methane yield [1]. In recent years, various biotechnologies have been developed to overcome the problems associated with the instability of the anaerobic digestion process, which will ultimately make it possible to restore maximum energy and simplify the anaerobic process [2-4].

Sugar beet pulp, a by-product of the sugar and ethanol industries, is composed of polysaccharides, proteins, lipids, and free sugars, and is processed into a dried beet pulp feed concentrate (DBP) [5]. During the production of ethanol from grain, a large amount of stillage by-product is formed. This by-product, containing yeast cells, proteins, lipids, crude fibers, amino acids, and free sugars, is often processed into a dried distillers grains with solubles feed concentrate (DDGS) by using an energy-intensive drying process [6]. Both by-products are extensively produced in the Russian Federation. However, complete utilization of beet pulp and stillage in animal nutrition is not possible, 
and these organic wastes are often recycled directly on the fields, which leads to serious environmental hazard to soil and water bodies. Thus, the application of sugar beet pulp and grain stillage as substrates for biomethane production is an alternative to decrease the energy consumption and greenhouse gas emissions in sugar and ethanol production processes by providing electricity and heat. This will stimulate the deployment of various biogas technologies, which is currently extremely slow in the Russian Federation.

The anaerobic digestion process is sensitive to disturbances because of the presence of different microorganisms, which participate in the four distinct steps such as hydrolysis, acidogenesis, acetogenesis, and finally methanogenesis. The last stage, methanogenesis, occurs through three major pathways: hydrogenotrophic, acetoclastic, and methylotrophic. To better understand the anaerobic digestion process, it is necessary to investigate the microbial community structure and dynamics in various reactor systems. Different molecular methods for identifying bacterial and archaeal communities involved in different stages of the anaerobic digestion process have been reported [7-10]. The investigation of the bacterial and archaeal communities involved in the anaerobic conversion of organic wastes to biogas in various types of anaerobic digesters is of practical interest to control this sensitive process, stabilize methanogenesis, reduce process instabilities, and finally increase the efficiency of operation of anaerobic reactors.

Several solutions have been proposed to improve the long-term stability of the anaerobic digestion processes, and one of the new trends in the anaerobic digestion process is the application of granular activated carbon (GAC), biochar, and $\mathrm{Fe}_{3} \mathrm{O}_{4}$ nanoparticles as additives to increase the methane production rate. Several researchers have reported that these agents can help to facilitate this effect [11-16]. GAC is an inexpensive substance, which is produced from carbonaceous source materials via physical and chemical activation, and it is frequently used as a biocarrier or adsorbent in a variety of wastewater treatment processes [17]. Recent studies have shown that GAC promotes methane production and substrate decomposition in several anaerobic systems [11,12]. Biochar is produced by using different processes, such as pyrolysis, gasification, and hydrothermal carbonization, and this material is inexpensive, environment-friendly, and can be used for various purposes [18]. Recent studies have demonstrated that the addition of biochar to different anaerobic digestion processes increased the biogas yield from various wastes [15,19]. In addition, naturally occurring Fe(III) minerals, such as magnetite $\left(\mathrm{Fe}_{3} \mathrm{O}_{4}\right)$, goethite $(\alpha-\mathrm{FeOOH})$, and hematite $\left(\alpha-\mathrm{Fe}_{2} \mathrm{O}_{3}\right)$, can promote methane production, as was shown in several anaerobic systems [16,20]. It has been demonstrated that electrically conductive materials, such as carbon materials and $\mathrm{Fe}_{3} \mathrm{O}_{4}$ nanoparticles, accelerate the anaerobic digestion process by supporting direct interspecies electron transfer (DIET) [16,19].

Thus, the main objective of the present study was to investigate the effects of granular activated carbon addition on the mesophilic anaerobic co-digestion of sugar beet pulp and distillers grains with solubles. The operation of anaerobic reactors was estimated in terms of methane production and accumulation of organic acids with their further degradation. In addition, bacterial and archaeal $16 \mathrm{~S}$ rRNA genes were investigated to characterize the structure and dynamics of different microbes inhabiting these anaerobic systems. Finally, possible mechanisms related to the increase in methane production in the presence of GAC were also discussed.

\section{Materials and Methods}

\subsection{Experimental Materials}

Dried sugar beet pulp (DBP; compressed pellets) and dried distillers grains with solubles (DDGS; compressed pellets) were used as substrates in the experiments instead of fresh substrates to ensure a consistent composition. DBP and DDGS were obtained from the Buinsky sugar factory and Buinsky distillery, respectively (Buinsk, the Republic of Tatarstan, Russia). Both facilities are located close to each other, which ensures the efficient by-products delivery. DBP had the total solids (TS) content of $91.9 \pm 0.17 \%$ and the volatile solids (VS) content of $88.5 \pm 0.08 \%$, while DDGS had the TS content 
of $92.8 \pm 0.12 \%$ and the VS content of $88.3 \pm 0.11 \%$. The original inoculum that was used to start up anaerobic reactors was digested cattle manure. Inoculum had the TS content of $4.7 \pm 0.17 \%$ and the VS content of $3.5 \pm 0.14 \%$ for the first set of experiments, while inoculum with the TS content of $6.3 \pm 0.31 \%$ and the VS content of $4.2 \pm 0.28 \%$ was used for the second set of experiments. This cattle manure was collected from a dairy farm located in the Zelenodolsky district (the Republic of Tatarstan, Russia). Coconut-based granular activated carbon (0.5-2.38 mm particle size; TS content of $96.7 \pm 0.3 \%$ ) was used in this research.

\subsection{Biochemical Methane Potential Experiments}

Biochemical methane potential (BMP) of DBP and DDGS was estimated by using Automatic Methane Potential Test Systems (AMPTS II Light, Bioprocess control, Lund, Sweden). During the first experiment, all batch anaerobic reactors were started using DBP (24.6 g of VS) and DDGS (10.5 g of VS) as substrates. During the second experiment, all batch reactors were started using DBP (19.9 $\mathrm{g}$ of VS) and DDGS (13.2 $\mathrm{g}$ of VS). Inoculum to substrate ratios (ISR) were 50.2/35.1 g of VS (1.43) and 44.1/33.1 $\mathrm{g}$ of VS (1.33) for the first and second treatments, respectively. The final TS concentrations reached $6.5 \%$ and $6.3 \%$ for the first and second treatments, accordingly. The $2000 \mathrm{~mL}$ bottles with a working volume of $1600 \mathrm{~g}$ were then incubated at $+38^{\circ} \mathrm{C}$ for $19-24$ days. GAC at concentrations of $1-10 \mathrm{~g} \mathrm{~L}^{-1}$ was selected and separately added to experimental reactors (labeled as G1-G6). Control reactors were operated without the addition of any methane-accelerating agents (labeled as $\mathrm{C} 1-\mathrm{C} 2$ ). The released biogas was first passed through a solution of $3 \mathrm{M} \mathrm{NaOH}$ to remove carbon dioxide and hydrogen sulfide, and the methane yield was estimated by using a gas flow meter system. Two biogas reactors served as blanks (one reactor contained inoculum and water, whereas the other one-inoculum, GAC, and water), and were used to compensate for the level of biomethane produced by inoculum itself in the absence and presence of GAC. Reactors were then flushed with $\mathrm{N}_{2}$ for about 2 min to achieve anaerobic conditions. The AMPTS II instrument agitated the digestion medium at $60 \mathrm{rpm}$ for $2 \mathrm{~min}$ with a $1 \mathrm{~min}$ rest interval. The batch tests were carried out in duplicates to ensure reproducibility.

\subsection{Analytical Methods}

Methane values were obtained automatically from AMPTS II instruments and were normalized to standard temperature and pressure conditions. Biogas released from reactors was periodically sampled and analyzed for gas composition using a Clarus 580 gas chromatograph (Perkin Elmer). Digestates were periodically taken from all batch reactors for various analyses (up to $10 \mathrm{~mL}$ per sample), including $\mathrm{pH}$, volatile organic acids (VOA), volatile organic acids to total inorganic carbon ratio (VOA/TIC), and total ammonia nitrogen (TAN), as well as microbial community structure analyses. TS and VS contents were estimated at the beginning and the end of the experimental period. These analyses were performed as detailed by Ziganshina et al. [21]. All these analyses were measured in triplicate, and the mean values are presented together with standard deviations (SD). The two-tailed $t$-test was used to compare differences in tests. $p$ values $<0.05$ were considered to indicate statistical significance.

\subsection{Microbial Community Structure}

Samples for the analysis of the structure and dynamics of microbial communities were collected from the second set of experiments at two different times (5th and 11th day of reactors' operation). A description of the methodology employed can be found in our previous works $[9,22,23]$. Briefly, total DNA was extracted and purified after centrifugation of digestates at $14,000 \times g$ for $10 \mathrm{~min}$, using a FastDNA spin kit for soil (MP Biomedicals). The DNA concentration was then quantified with a Qubit 2.0 Fluorometer (Thermo Fisher Scientific). Primers Bakt_341F (5'-CCT ACG GGN GGC WGC AG-3') and Bakt_805R (5'-GAC TAC HVG GGT ATC TAA TCC-3') were used to amplify the bacterial 16S rRNA gene, while primers Arch349F (5'-GYG CAS CAG KCG MGA AW-3') and Arch806R (5' -GGA CTA CVS GGG TAT CTA AT-3') were used to amplify the archaeal 16S rRNA gene. Sequencing was carried out with an Illumina MiSeq sequencing platform with MiSeq Reagent Kit v3 (600 cycles), 
according to the manufacturer's instructions. The obtained sequence data were then analyzed with QIIME 1.9.1 [24]. High-quality 16S rRNA gene sequences were clustered into molecular operational taxonomic units (OTUs) (clustering threshold is 97\% identity). OTUs representing less than $0.01 \%$ of the total reads were also excluded. Alpha diversity indices were assessed on an OTU level. For the taxonomic assignment of OTUs, the MiDAS database [25] was used.

\section{Results and Discussion}

\subsection{Process Stability and Methane Production}

Anaerobic conversion of beet pulp and distillers grains with solubles was carried out in the presence of granular activated carbon at different concentrations of 1-10 $\mathrm{g} \mathrm{L}^{-1}$, considering the stimulating effect and further practical application of GAC. Since sugar beet pulp is recommended to be digested together with other types of substrates [26], in our experiments, beet pulp was anaerobically co-digested with distillers grains with solubles. During the first batch experiments (ISR 1.43), five different conditions were monitored: control reactors (C1) and reactors supplemented with GAC $\left(1 \mathrm{~g} \mathrm{~L}^{-1}(\mathrm{G} 1), 2 \mathrm{~g} \mathrm{~L}^{-1}(\mathrm{G} 2)\right.$, $5 \mathrm{~g} \mathrm{~L}^{-1}(\mathrm{G} 3)$, and $\left.10 \mathrm{~g} \mathrm{~L}^{-1}(\mathrm{G} 4)\right)$. The mesophilic reactors were operated for 24 days, and during this period, four samples were collected from each reactor to study the composition of the digested mixture. Figures 1 and 2 show specific methane production (SMP), methane flow rate, $\mathrm{pH}$ values, organic acids concentrations, and VOA/TIC values. Total ammonia nitrogen (TAN) concentrations are given in Table 1.

Figure 1 shows the methane yields from the DBP/DDGS-fed incubations in the absence and presence of GAC. As can be seen, methane was produced efficiently in all cases, indicating that both substrates tested in this research are suitable for anaerobic digestion. After a noticeably short period (1-2 h), anaerobic reactors started to produce methane and were ready for completion within 24 days. After 1 day of incubation, similar methane yields were obtained for all treatments and the average data ranged from 1186 to $1248 \mathrm{~mL}$. After 6 days of anaerobic digestion, reactors supplied with GAC produced more methane compared to control treatments. Thus, the average methane volumes from reactors C1, G1, G2, G3, and G4 reached $5816 \mathrm{~mL}, 6045 \mathrm{~mL}, 6039 \mathrm{~mL}, 6632 \mathrm{~mL}$, and $6422 \mathrm{~mL}$ on day 6, respectively. The maximum peaks in methane production in all five treatments were $1286 \mathrm{~mL}, 1359 \mathrm{~mL}$ $1335 \mathrm{~mL}, 1462 \mathrm{~mL}$, and $1414 \mathrm{~mL}$, respectively, and the corresponding times were day 6 for reactors $\mathrm{C} 1, \mathrm{G} 1$, and G2, and day 5 for reactors G3 and G4, respectively. For the groups with 5-10 g L ${ }^{-1} \mathrm{GAC}_{\text {, }}$ most of the methane was produced by day 13, while its release tended to a plateau on days 14-15 for the control group and the group with 1-2 $\mathrm{g} \mathrm{L}^{-1} \mathrm{GAC}$, respectively. The addition of GAC enhanced the methane production rate, and the maximum methane production rate increased by $13.7 \%$ in the presence of GAC $\left(5 \mathrm{~g} \mathrm{~L}^{-1}\right)$, compared to control reactors $(p=0.03)$. These results clearly indicate that the addition of GAC at appropriate dosages leads to an increase in methane flow rate. However, this additive did not improve the final production of methane $(p>0.05)$. Finally, specific methane

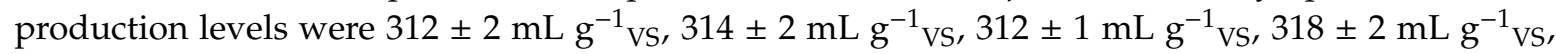
and $308 \pm 3 \mathrm{~mL} \mathrm{~g}^{-1}$ vs from all five incubations $(0 \mathrm{~g}, 1 \mathrm{~g}, 2 \mathrm{~g}, 5 \mathrm{~g}$, and $10 \mathrm{~g}$ of GAC per $1 \mathrm{~L}$, respectively).

During the anaerobic digestion process, the $\mathrm{pH}$ values in reactors initially decreased from an initial 7.30-7.33 to 6.98-7.08 on day 4, increased on day 7, and finally decreased to 7.52-7.57, as shown in Figure 2a. As important intermediates in anaerobic digestion, temporal changes in organic acids levels were observed at intervals of 4-13 days (Figure 2 b). It has been observed that organic acids consumption is clearly influenced by the addition of GAC. Overall, the concentrations of the accumulated organic acids were high, due to a large amount of organic matter in the beet pulp and distillers grains with solubles. The addition of GAC (1-10 $\left.\mathrm{g} \mathrm{L}^{-1}\right)$ significantly decreased the concentrations of accumulated organic acids during the initial period of anaerobic digestion $(p<0.01)$. For example, on day 4 , the average acid capacity in anaerobic reactors $\mathrm{C} 1, \mathrm{G} 1, \mathrm{G} 2, \mathrm{G} 3$, and G4 reached $9.34 \mathrm{~g} \mathrm{~L}^{-1}, 8.69 \mathrm{~g} \mathrm{~L}^{-1}$, $8.61 \mathrm{~g} \mathrm{~L}^{-1}, 7.34 \mathrm{~g} \mathrm{~L}^{-1}$, and $7.48 \mathrm{~g} \mathrm{~L}^{-1}$, respectively. This suggests that the methane-producing activity in reactors without GAC was insufficient at the beginning of the experiments, which ultimately influenced the methane flow rate. Finally, during anaerobic digestion, organic acids in all reactors were efficiently 
funneled into methanogenesis. The buffer capacity of anaerobic digesters was also analyzed by total alkalinity. The VOA/TIC ratio in G1, G2, G3, and G4 increased initially to average values of 2.38, 2.29, $2.13,1.99$, and 2.02, but then decreased to $0.09-0.13$, as demonstrated in Figure 2c. The obtained data indicate that the addition of GAC (mainly $5 \mathrm{~g} \mathrm{~L}^{-1}$ and $10 \mathrm{~g} \mathrm{~L}^{-1}$ ) improved the performance of these reactors. Our results are consistent with several other studies that have shown that various organic acids decompose faster, due to the presence of additives such as granular activated carbon, but in other anaerobic systems [11,12].

Anaerobic digestion of DBP and DDGS was accompanied by the accumulation of TAN (Table 1). TAN levels increased from $0.95-1.00 \mathrm{~g} \mathrm{~L}^{-1}$ (day 4) to $1.20-1.27 \mathrm{~g} \mathrm{~L}^{-1}$ (day 24) in different reactors. Ammonium toxicity should not affect the activity of the methanogenic community in each reactor, since the $\mathrm{NH}_{4}{ }^{+}-\mathrm{N}$ concentrations in digestates from all reactors were almost the same. These values are typical for well-established anaerobic biogas-generating systems [27,28].
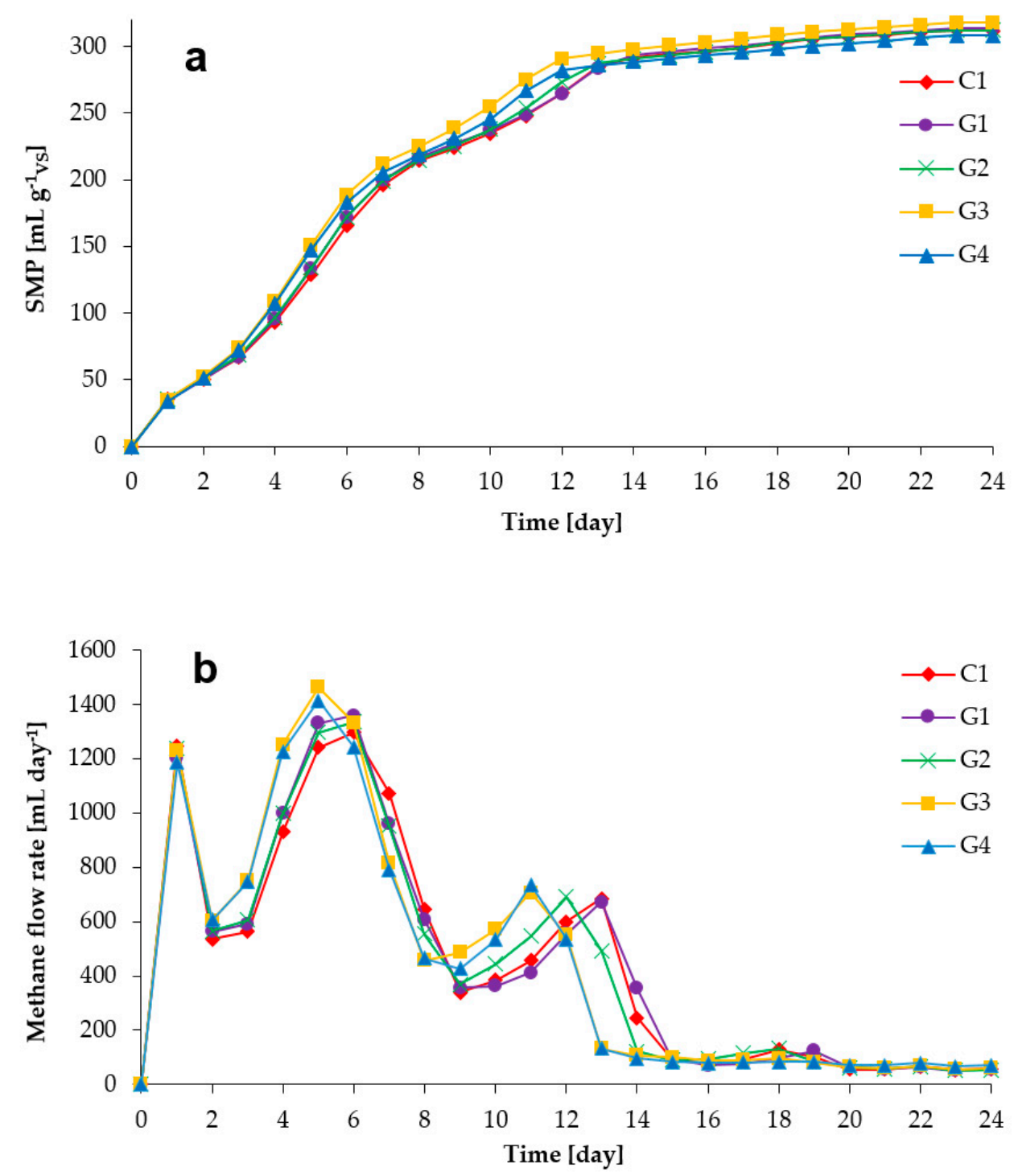

Figure 1. Effects of granular activated carbon (GAC) addition on specific methane production (SMP) (a) and methane flow rate (b) during the experimental period (inoculum to substrate ratio (ISR) is 1.43). Different concentrations of GAC $\left(0 \mathrm{~g} \mathrm{~L}^{-1}, 1 \mathrm{~g} \mathrm{~L}^{-1}, 2 \mathrm{~g} \mathrm{~L}^{-1}, 5 \mathrm{~g} \mathrm{~L}^{-1}\right.$, and $\left.10 \mathrm{~g} \mathrm{~L}^{-1}\right)$ were added to reactors (C1, G1, G2, G3, and G4, respectively). 

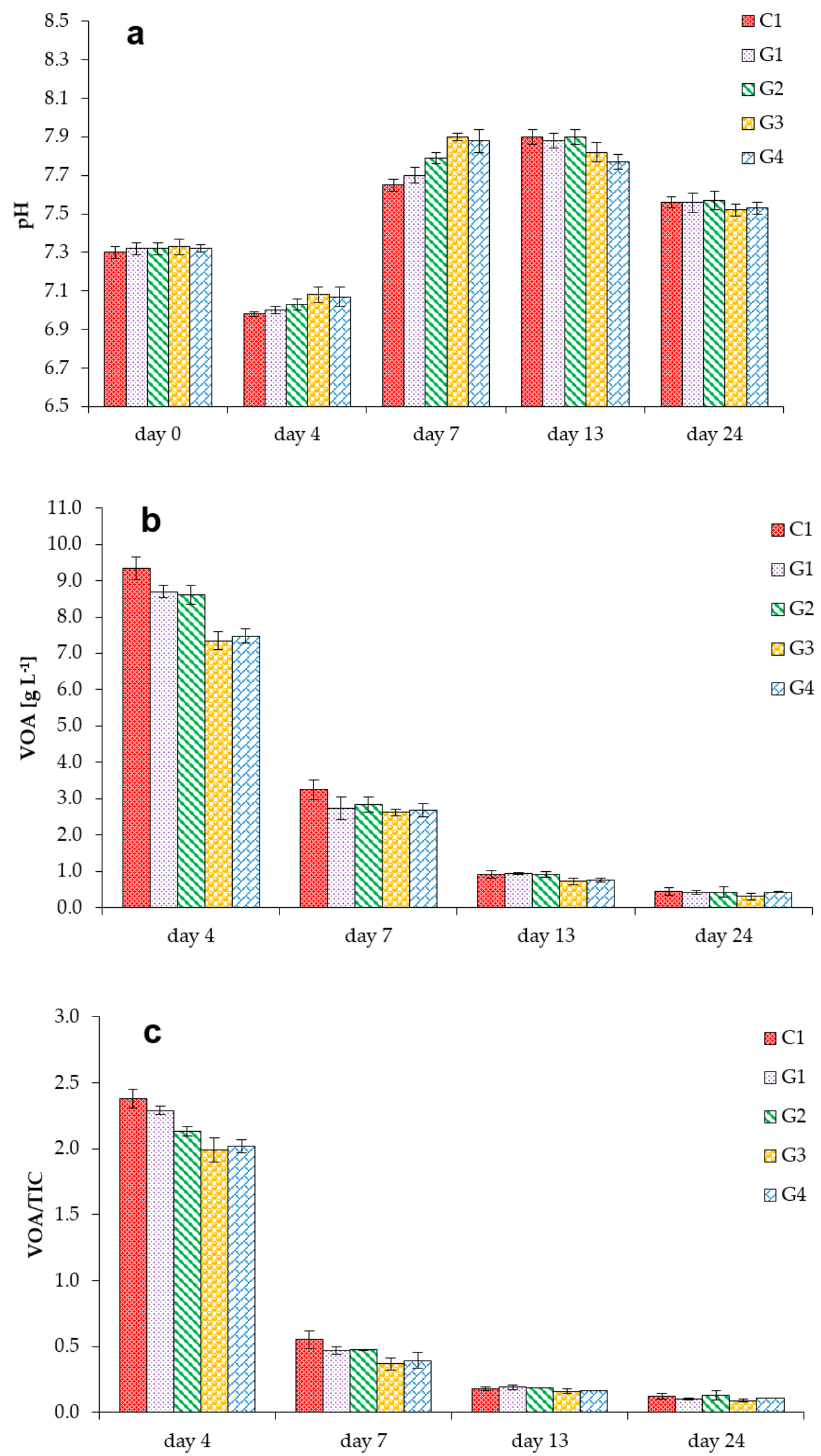

Figure 2. Effects of GAC addition on $\mathrm{pH}$ changes (a), VOA concentrations (b), and the ratio of volatile organic acids to total inorganic carbon (VOA/TIC) (c) during the experimental period (ISR is 1.43). Different concentrations of GAC $\left(0 \mathrm{~g} \mathrm{~L}^{-1}, 1 \mathrm{~g} \mathrm{~L}^{-1}, 2 \mathrm{~g} \mathrm{~L}^{-1}, 5 \mathrm{~g} \mathrm{~L}^{-1}\right.$, and $\left.10 \mathrm{~g} \mathrm{~L}^{-1}\right)$ were added to reactors (C1, G1, G2, G3, and G4, respectively). 
Table 1. Total ammonia nitrogen concentration $\left(\mathrm{g} \mathrm{L}^{-1}\right)$ detected in reactors (mean $\pm \mathrm{SD}$ ).

\begin{tabular}{cccccc}
\hline Reactor & Day 4 & Day 24 & Reactor & Day 5 & Day 19 \\
\hline C1 & $0.950 \pm 0.02$ & $1.205 \pm 0.10$ & C2 & $0.970 \pm 0.04$ & $1.020 \pm 0.05$ \\
G1 & $0.972 \pm 0.02$ & $1.244 \pm 0.07$ & G5 & $0.977 \pm 0.02$ & $1.001 \pm 0.08$ \\
G2 & $0.988 \pm 0.04$ & $1.218 \pm 0.11$ & G6 & $0.974 \pm 0.03$ & $1.005 \pm 0.09$ \\
G3 & $1.002 \pm 0.03$ & $1.269 \pm 0.06$ & & & \\
G4 & $0.996 \pm 0.04$ & $1.239 \pm 0.08$ & & & \\
\hline
\end{tabular}

In accordance with our previous experiments on the changes in methane production caused by various concentrations of granular activated carbon, GAC at concentrations of $5 \mathrm{~g} \mathrm{~L}^{-1}$ and $10 \mathrm{~g} \mathrm{~L}^{-1}$ were selected as the optimal dosages for the anaerobic conversion of DBP and DDGS for the second batch experiments (ISR 1.33). Therefore, during the entire period, different conditions were monitored: control reactors (C2) and reactors supplemented with GAC (5 g L $\mathrm{L}^{-1}$ (G5) and $10 \mathrm{~g} \mathrm{~L}^{-1}$ (G6)). The mesophilic reactors were operated for 19 days, and during this period several samples were obtained for each reactor to analyze the composition of the digested mixture and microbial community structure and dynamics. Figures 3 and 4 show the SMP, methane flow rate, $\mathrm{pH}$ values, VOA concentrations, VOA/TIC ratio, while Table 1 shows the TAN concentrations in these reactors.

During the first 4 days, a gap in methane production from each group was obvious, and the accumulated average methane volumes reached $3083 \mathrm{~mL}, 4658 \mathrm{~mL}$, and $3935 \mathrm{~mL}$ in C2, G5, and G6, respectively, on day 4 . The average maximum peaks of methane production in all three experiments (C2, G5, and G6) were $1372 \mathrm{~mL}, 1555 \mathrm{~mL}$, and $1431 \mathrm{~mL}$, respectively, and the corresponding times were the day 5 (for C2) and day 4 (for G5 and G6). In these experiments, the maximum methane production rate increased by $13.4 \%$ in the presence of GAC $\left(5 \mathrm{~g} \mathrm{~L}^{-1}\right)$, compared to the control reactors $(p=0.04)$. This indicates that GAC can enhance methanogenesis. However, after 19 days of anaerobic digestion, the specific methane production was comparable between all treatments and reached $305 \pm 2 \mathrm{~mL} \mathrm{~g}^{-1} \mathrm{VS}$, $307 \pm 2 \mathrm{~mL} \mathrm{~g}^{-1} \mathrm{vS}$, and $300 \pm 3 \mathrm{~mL} \mathrm{~g}^{-1} \mathrm{vS}$ in reactors C2, G5, and G6, respectively (Figure 3). During the anaerobic digestion process, the $\mathrm{pH}$ values in reactors initially decreased from an initial 7.51-7.54 to 6.91-7.12 on day 5, but eventually reached 7.33-7.36 (Figure 4a). The lowest $\mathrm{pH}$ values were observed in $\mathrm{C} 2$ on day 5 . Figure $4 \mathrm{~b}$ shows the change of organic acids levels during the 19-day experimental period. The organic acids in all reactors rapidly peaked during the initial 5 days, but finally dropped to $0.28-0.43 \mathrm{~g} \mathrm{~L}^{-1}$ by the end of the anaerobic digestion process. The organic acids content in the GAC-free group was significantly higher than that observed in the GAC-containing group on days 5 and $11(p<0.01)$. For example, on day 5, acid capacity in reactors C2, G5, and G6 reached average values of $6.03 \mathrm{~g} \mathrm{~L}^{-1}, 3.50 \mathrm{~g} \mathrm{~L}^{-1}$, and $4.43 \mathrm{~g} \mathrm{~L}^{-1}$, respectively. It was noted that the utilization of organic acids was clearly influenced by the addition of GAC. The VOA/TIC ratio in reactors C2, G5, and G6 initially reached average values of $1.22,0.62$, and 0.76 , but eventually decreased to $0.07-0.11$, as shown in Figure 4c. Comparable TAN levels were found in all reactors (in the range of $1.00-1.02 \mathrm{~g} \mathrm{~L}^{-1}$ on day 19; Table 1).

The physical characteristics of GAC and biochar promote the formation of biofilms on their surfaces, which can increase the resistance of microbes to various inhibitory compounds. Also, these additives facilitate the syntrophic interactions required for the degradation of volatile fatty acids and finally increase the methane production rate. By reducing the distance between microorganisms that carry out mediated interspecies electron transfer (MIET), the reaction kinetics are enhanced, and the concentrations of electron shuttles and other fermentation products in the reaction media are reduced. Moreover, such carbon-based materials adsorb various inhibitory components [12,29] and allow DIET occurring on their surfaces [30]. It has previously been demonstrated that conductive carbon materials, including GAC and biochar, as well as iron-bearing minerals, such as magnetite, perform DIET that accelerates the anaerobic digestion process. It is expected that DIET is a faster and more efficient electron transport mechanism than MIET [31]. Therefore, it can be assumed that a better understanding 
of the mechanisms of DIET will ultimately lead to improved design of digesters, which will contribute to DIET and further stabilize the anaerobic digestion process.
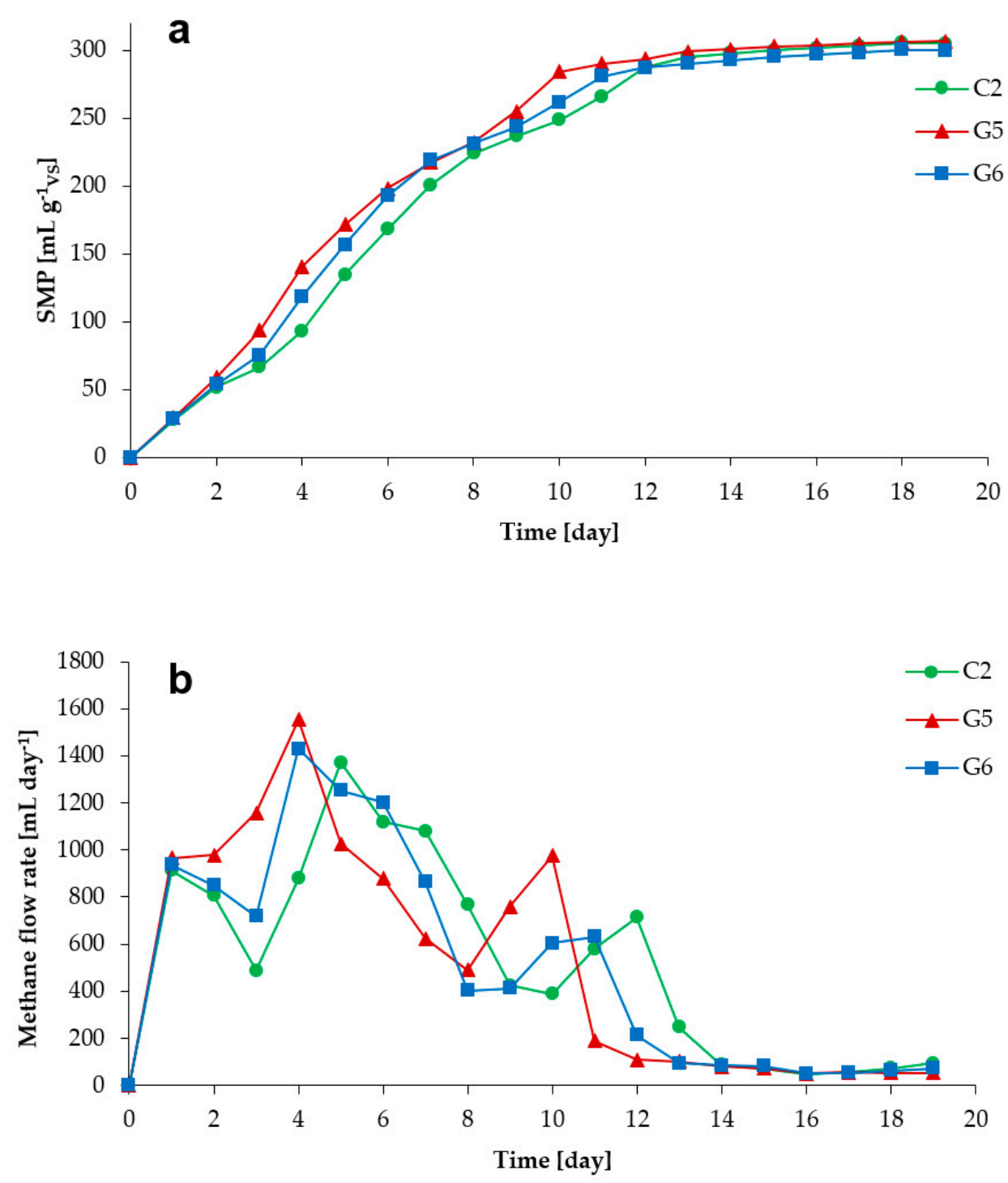

Figure 3. Effects of GAC addition on specific methane production (a) and methane flow rate (b) during the experimental period (ISR is 1.33). Different concentrations of GAC $\left(0 \mathrm{~g} \mathrm{~L}^{-1}, 5 \mathrm{~g} \mathrm{~L}^{-1}\right.$, and $\left.10 \mathrm{~g} \mathrm{~L}^{-1}\right)$ were added to reactors (C2, G5, and G6, respectively).

Yang et al. [11] showed that the addition of GAC up to $5 \mathrm{~g}$ per $150 \mathrm{~mL}$ increased the methane production by $17.4 \%$ during the anaerobic digestion of sludge, and enhanced the conversion of propionate to acetate. The results obtained by Capson-Tojo et al. [12] indicated that the addition of activated carbon at a concentration of $10 \mathrm{~g} \mathrm{~L}^{-1}$ favored biomass acclimatization, which led to improved acetic acid consumption and enhanced methane production from food waste. The addition of activated carbon promoted the growth of methanogenic archaea and syntrophic bacteria, which indicates an increased interaction between these microorganisms and higher biomass concentrations. Peng et al. [13] demonstrated that the addition of GAC $\left(27 \mathrm{~g} \mathrm{~L}^{-1}\right)$ and magnetite $\left(13.5 \mathrm{~g} \mathrm{~L}^{-1}\right)$ to anaerobic digesters simultaneously enhanced both sludge hydrolysis and methane production rate. Barua et al. [32] showed that GAC particles doped with magnetite can substantially improve the syntrophic biodegradation of propionate. However, the influence of GAC on the anaerobic digestion processes should be investigated with various substrates and inocula, to clarify the effects in more detail. 

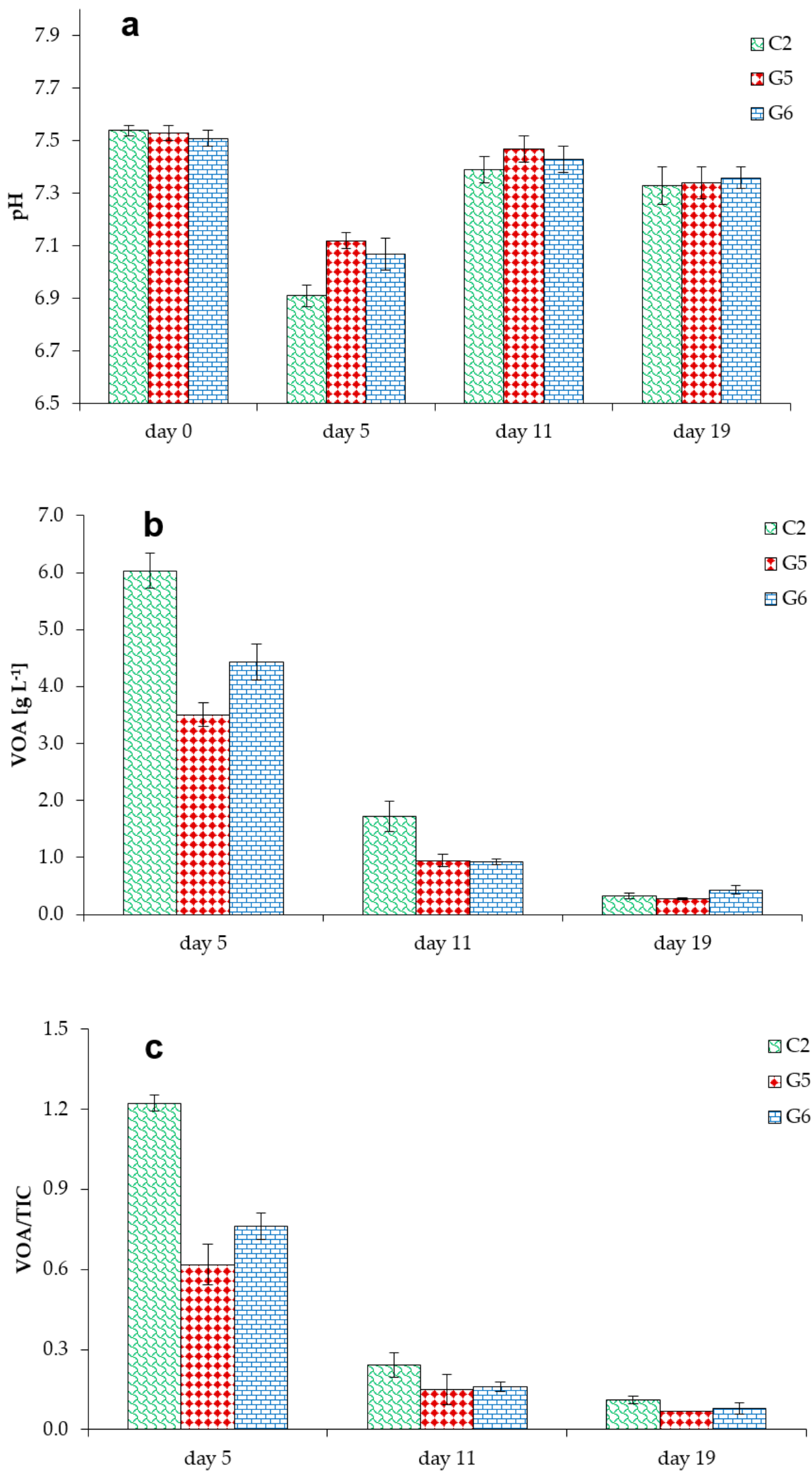

Figure 4. Effects of GAC addition on $\mathrm{pH}$ changes (a), VOA concentrations (b), and VOA/TIC (c) during the experimental period (ISR is 1.33). Different concentrations of GAC $\left(0 \mathrm{~g} \mathrm{~L}^{-1}, 5 \mathrm{~g} \mathrm{~L}^{-1}\right.$, and $\left.10 \mathrm{~g} \mathrm{~L}^{-1}\right)$ were added to reactors (C2, G5, and G6, respectively). 


\subsection{Bacterial Community Structure}

Six samples were taken from reactors to analyze the structure of microbial communities (on days 5 and 11). Starting with the bacterial communities, the predominant phylotypes in all reactors (C2, G5, and G6) were similar. More than 146 thousand high-quality bacterial sequences were received, and the mean number of reads per sample was 24,349 (ranging from 11,194 to 33,382). In general, amplicon sequencing covered most of the bacterial phylotypes, which were observed in six samples. Alpha diversity indices calculated on the OTU level for each sample are shown in Table 2. The number of bacterial OTUs in six samples ranged from 417 to 558 (abundance $>0.01 \%$ ), decreased both in GAC-free and GAC-containing reactors towards the end of the experimental period, but was higher in GAC-containing reactors.

Table 2. Alpha diversity of microbial communities.

\begin{tabular}{ccccccccc}
\hline \multirow{2}{*}{ Sample } & \multicolumn{3}{c}{ Bacteria } & \multicolumn{3}{c}{ Archaea } \\
\cline { 2 - 8 } & OTUs & Chao1 & Shannon & Simpson & OTUs & Chao1 & Shannon & Simpson \\
\hline C2 (day 5) & 508 & 538 & 6.79 & 0.98 & 82 & 94 & 1.63 & 0.56 \\
C2 (day 11) & 417 & 479 & 6.65 & 0.98 & 92 & 96 & 2.88 & 0.76 \\
G5 (day 5) & 523 & 552 & 6.77 & 0.98 & 93 & 99 & 2.51 & 0.69 \\
G5 (day 11) & 513 & 571 & 6.74 & 0.98 & 93 & 93 & 2.91 & 0.76 \\
G6 (day 5) & 558 & 576 & 7.00 & 0.98 & 88 & 88 & 2.12 & 0.63 \\
G6 (day 11) & 502 & 534 & 6.47 & 0.97 & 85 & 87 & 2.78 & 0.75 \\
\hline
\end{tabular}

The relative abundance of various bacterial groups was analyzed on different taxonomic levels, such as phylum, class, order, family, and genus. As a result, 19 phyla, 33 classes, 49 orders, 94 families, and 200 genera were detected in six samples. The structure and dynamics of bacterial communities (on the class level) in different anaerobic reactors is illustrated in Figure 5. The prevailed bacterial classes in GAC-free and GAC-containing anaerobic reactors were Clostridia and Bacteroidia, which accounted for $42.8 \%$ and $32.2 \%$ of the total bacterial $16 \mathrm{~S}$ rRNA gene sequences, respectively. Other classes representing more than $1 \%$ of the bacterial $16 \mathrm{~S}$ rRNA gene sequences in all samples were Actinobacteria, Gammaproteobacteria, Spirochaetia, and Synergistia.

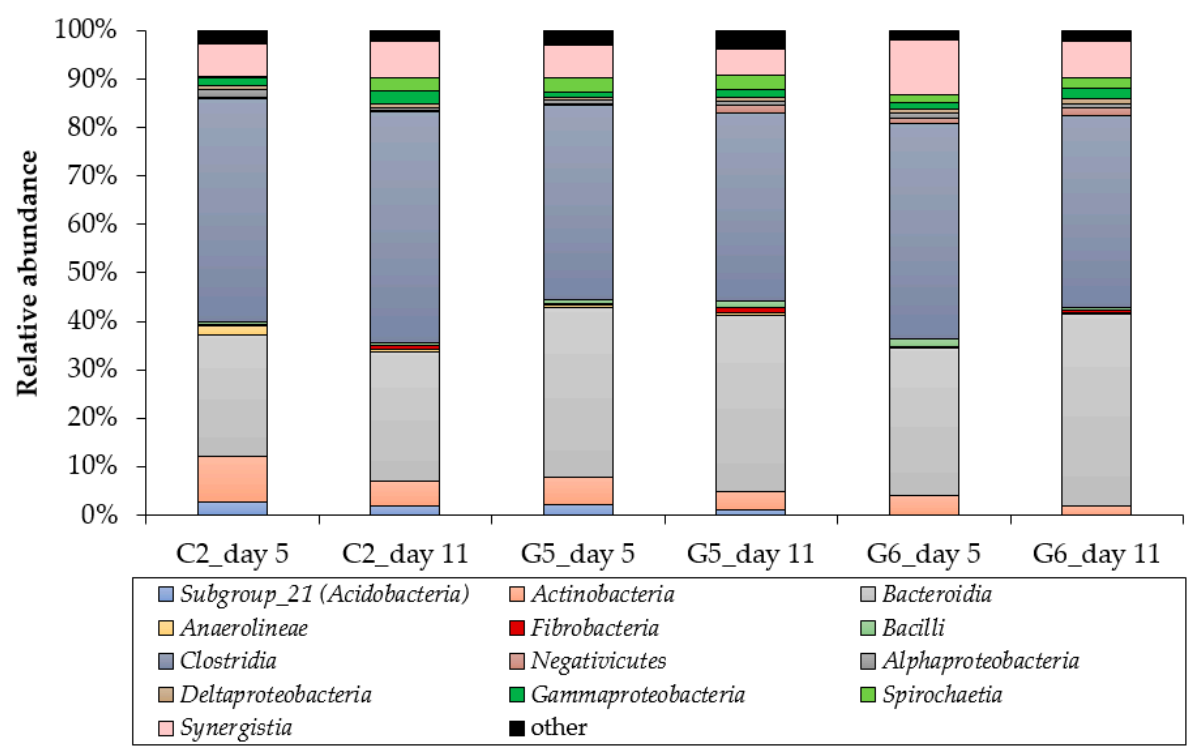

Figure 5. Taxonomic composition of bacterial communities in reactors C2, G5, and G6 (sampled on days 5 and 11). Bacterial community composition according to amplicon sequencing of the bacterial $16 \mathrm{~S}$ rRNA gene is shown on the class level. Only classes with a relative abundance of at least $1 \%$ in at least one sample are presented. 
Figure 6 shows a heat map of the relative abundances of the most common genera, which were observed in different samples.

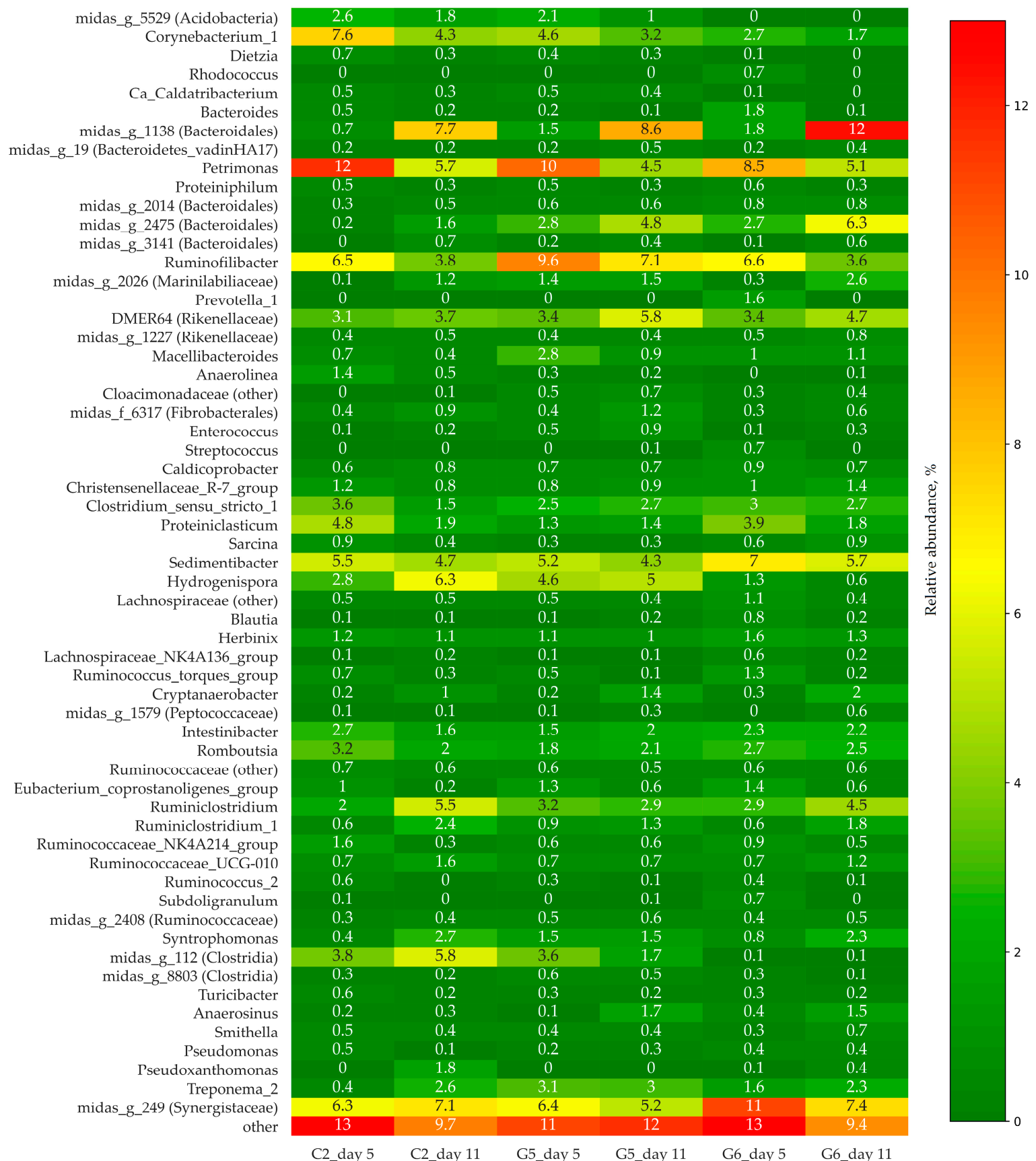

Figure 6. Heatmap illustrating the relative abundances of bacterial taxa in reactors C2, G5, and G6 (sampled on days 5 and 11). Bacterial community composition according to amplicon sequencing of the bacterial 16S rRNA gene is shown on the genus level. Only taxa comprising at least $1 \%$ relative abundance in at least one sample are presented.

The structure of the bacterial community in all reactors C2, G5, and G6 was unstable throughout the experimental period with a decrease in the relative abundance of representatives of the genera Corynebacterium_1, Petrimonas, Ruminofilibacter, Proteiniclasticum, Sedimentibacter, and an increase in the relative abundance of midas_g_1138, midas_g_2475 (Bacteroidales), Ruminiclostridium (including Ruminiclostridium_1), as well as several others in all reactors (Figure 6). Members of the genus Corynebacterium are facultatively anaerobic or aerobic bacteria that are widespread in the environment 
and produce different organic acids from various sugars [33]. Petrimonas is a genus of strictly anaerobic bacteria that ferment various carbohydrates and organic acids. Petrimonas sulfuriphila produces acetic acid, hydrogen, and carbon dioxide during the fermentation of glucose [34]. Ruminofilibacter xylanolyticum is a rumen bacterium with a pronounced hydrolytic enzyme activity towards xylan, which has also been found in other anaerobic biogas reactors $[35,36]$. The anaerobic genus Proteiniclasticum, which includes proteolytic bacteria, ferments peptone-yeast medium to form acetic, propionic, and iso-butyric acids [37]. Sedimentibacter species are strictly anaerobic, require yeast extract for growth, and produce acetic, propionic, and butyric acids, but only from several substrates [38,39]. Ruminiclostridium cellobioparum, as a representative of the genus Ruminiclostridium, produces formic, acetic, lactic, butyric acids, ethanol, hydrogen, and carbon dioxide during sugar fermentation [40].

Interestingly, the relative abundances of the genera midas_g_2475 (Bacteroidales) and DMER64 (Rikenellaceae) were higher in GAC-containing treatments than those observed in the GAC-free treatments. In addition, member of the genus Syntrophomonas (closely related to Syntrophomonas sapovorans) was found at higher levels on day 5 in reactors G5 and G6. The genus DMER64 of the family Rikenellaceae has been proposed as a potential syntrophic bacterial group that can create magnetite-mediated DIET with several methanogenic archaea [41]. However, more research is needed to test the possibility of these microorganisms to mediate DIET in GAC-containing systems. Species of the anaerobic genus Syntrophomonas are syntrophic fatty acids degrading bacteria that are found in various anaerobic environments. The species Synthrophomonas sapovorans degrades even-numbered fatty acids to propionic acid, acetic acid, and molecular hydrogen in co-culture with hydrogen-utilizing methanogenic archaea, such as Methanospirillum hungatei [42]. Syntrophomonas wolfei oxidizes saturated fatty acids in co-culture with $\mathrm{H}_{2}$-utilizing Desulfovibrio spp. or M. hungatei [43]. The species of the genus Syntrophomonas have also been proposed to participate in the DIET mechanism as electron-donating partners in the presence of $\mathrm{Fe}_{3} \mathrm{O}_{4}$ nanoparticles [44,45]; however, there was no direct evidence of the DIET mechanism during the conversion of butyrate to methane by S. wolfei and M. hungatei in the presence of carbon nanotubes, although the syntrophy was increased by 1.5 times [46].

\subsection{Archaeal Community Structure}

When looking at the archaeal communities (days 5 and 11), more than 165 thousand high-quality sequences were acquired after analysis of six samples, and the mean number of reads per one sample was 27,476 (ranging from 23,440 to 30,677 ). Alpha diversity indices calculated on the OTU level for each sample are presented in Table 2. The number of archaeal OTUs in six analyzed samples ranged from 82 to 93 (abundance $>0.01 \%$ ) and was comparable in GAC-free and GAC-containing anaerobic reactors.

The corresponding sequencing results (on the genus level) are presented in Figure 7. From these results, it can be seen that the predominant phylotypes were similar in all anaerobic reactors $(\mathrm{C} 2, \mathrm{G} 5$, and G6). During the entire experimental period, the most detected methanogenic genera in GAC-free (C2) and GAC-containing (G5 and G6) anaerobic reactors were Methanosarcina and Methanoculleus. Members of the genus Methanosarcina are acetoclastic, hydrogenotrophic, and methylotrophic methanogens $[47,48]$. Representatives of the genus Methanoculleus are hydrogenotrophic methanogens that grow and produce methane from either $\mathrm{H}_{2} / \mathrm{CO}_{2}$ or formate [49]. The relative abundance of representatives of the genus Methanosarcina decreased, whereas the relative abundance of members of the genera Methanoculleus, Methanothrix, and Methanomassiliicoccus increased during operation of all reactors. Methanothrix (Methanosaeta) species are methanogenic archaea that perform acetoclastic methanogenesis [50], whereas Methanomassiliicoccus luminyensis utilizes methanol $+\mathrm{H}_{2}$ and methylamines $+\mathrm{H}_{2}$, but cannot reduce $\mathrm{CO}_{2}$ to $\mathrm{CH}_{4}$ [51]. Additionally, it should be noted that on day 5 , when high differences in gas production were detected, a higher level of the genera Methanoculleus, Methanothrix, and Methanomassiliicoccus was observed in GAC-containing reactors. 


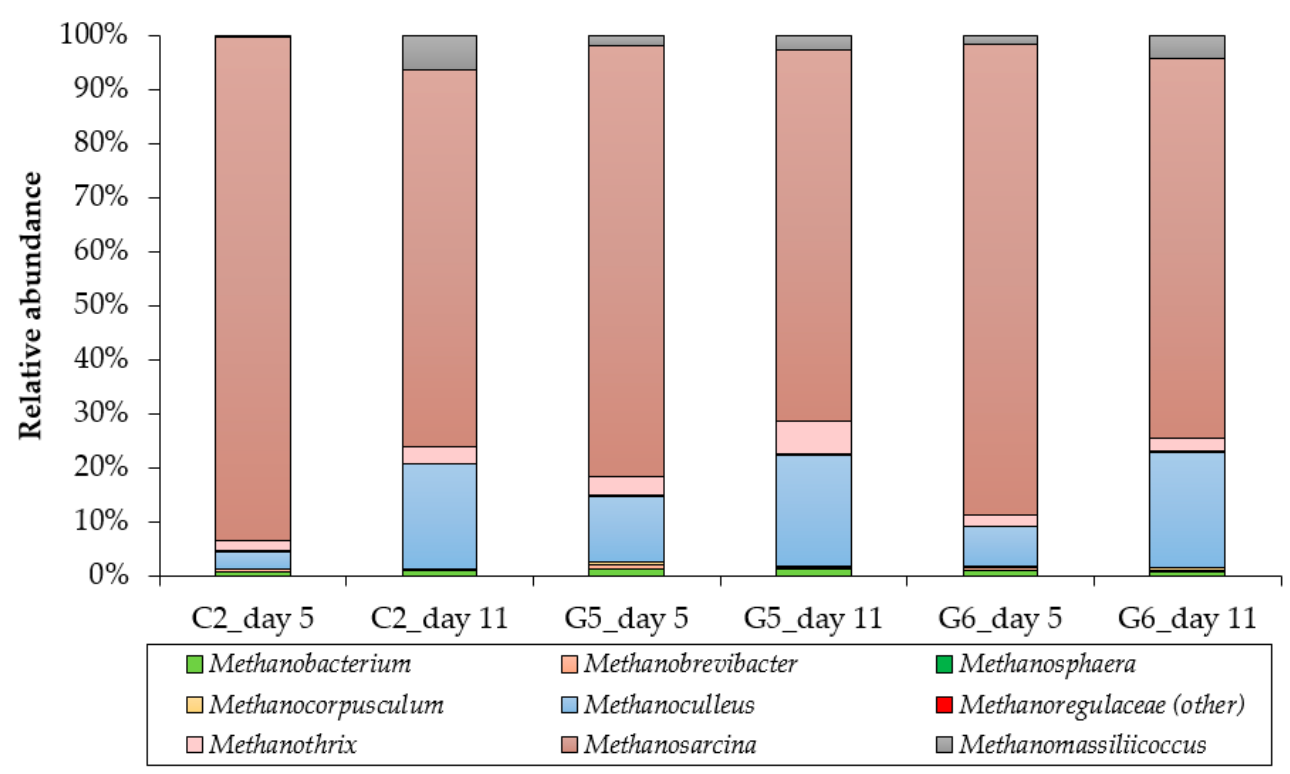

Figure 7. Taxonomic composition of the methanogenic communities in reactors C2, G5, and G6 (sampled on days 5 and 11). Methanogenic community composition according to amplicon sequencing of the archaeal 16S rRNA gene is shown on the genus level.

The abundance of the genus Methanothrix (Methanosaeta) was higher in GAC-containing reactors, and these methanogens could participate both in acetoclastic methanogenesis and DIET-mediated carbon dioxide reduction, as previously reported by Rotaru et al. [52]. Moreover, several species of the genus Methanosarcina can also be involved in the DIET mechanism [53], but they have been detected at high levels in all our reactors. The DIET mechanism has been established for both methanogenic archaea in coculture with Geobacter metallireducens; however, 16S rRNA gene sequences belonging to G. metallireducens could not be amplified in all our anaerobic batch reactors. Instead, some other potential syntrophic bacteria (midas_g_2475, DMER64, or others) may establish GAC-mediated direct electron transfer with methanogens (e.g., Methanothrix); however, further study of this mechanism is required.

\section{Conclusions}

Our results indicate that the addition of granular activated carbon at appropriate dosages has positive effects on the anaerobic digestion process of waste products of the processing of sugar beet and the ethanol distillation process in batch tests. Here, we demonstrate that methane is produced faster mostly in the presence of $5 \mathrm{~g} \mathrm{~L}^{-1}$ and $10 \mathrm{~g} \mathrm{~L}^{-1}$ of GAC than in GAC-free incubations. The addition of GAC significantly reduces the concentrations of accumulated organic acids during the whole anaerobic digestion period and enhances the methane flow rate. Thus, the GAC addition and adapted microbial consortia can be used as a remedy in case of a malfunction of anaerobic reactors (in particular, during disturbances of methanogenesis, because of the accumulation of inhibitory intermediates, such as volatile fatty acids). However, to confirm this, additional experiments are required.

Author Contributions: Conceptualization, E.E.Z. and A.M.Z.; methodology, E.E.Z. and A.M.Z.; software, E.E.Z., D.E.B., S.S.B. and A.M.Z.; validation, E.E.Z., D.E.B., S.S.B. and A.M.Z.; formal analysis, E.E.Z., D.E.B., S.S.B. and A.M.Z.; investigation, E.E.Z., D.E.B., S.S.B. and A.M.Z.; resources, A.M.Z.; data curation, E.E.Z. and A.M.Z.; writing —original draft preparation, E.E.Z.; writing—review and editing, D.E.B., S.S.B. and A.M.Z.; visualization, E.E.Z.; supervision, A.M.Z.; project administration, A.M.Z.; funding acquisition, A.M.Z. All authors have read and agreed to the published version of the manuscript.

Funding: The reported study was funded by the Russian Foundation for Basic Research [Grant No. 18-29-25058].

Acknowledgments: We would like to thank the technicians of the Department of Microbiology (KFU) for their support during the implementation of the project. 
Conflicts of Interest: The authors declare no conflict of interest. The funders had no role in the design of the study; in the collection, analyses, or interpretation of data; in the writing of the manuscript, or in the decision to publish the results.

\section{References}

1. Maurya, R.; Tirkey, S.R.; Rajapitamahuni, S.; Ghosh, A.; Mishra, S. Chapter 9-Recent advances and future prospective of biogas production. In Advances in Feedstock Conversion Technologies for Alternative Fuels and Bioproducts, 1st ed.; Hosseini, M., Ed.; Woodhead Publishing: Cambridge, UK, 2019; pp. 159-178. [CrossRef]

2. Siciliano, A.; Limonti, C.; Curcio, G.M.; Calabrò, V. Biogas generation through anaerobic digestion of compost leachate in semi-continuous completely stirred tank reactors. Processes 2019, 7, 635. [CrossRef]

3. Holder, N.; Mota-Meira, M.; Born, J.; Sutrina, S.L. Bio-methane production via anaerobic co-digestion by optimizing the mixing ratios of river tamarind (Leucaena leucocephala) and dolphin fish (Coryphaena hippurus) offal. Processes 2020, 8, 934. [CrossRef]

4. Cruz-Salomón, A.; Ríos-Valdovinos, E.; Pola-Albores, F.; Lagunas-Rivera, S.; Cruz-Rodríguez, R.I.; Cruz-Salomón, K.C.; Hernández-Méndez, J.M.E.; Domínguez-Espinosa, M.E. Treatment of cheese whey wastewater using an expanded granular sludge bed (EGSB) bioreactor with biomethane production. Processes 2020, 8, 931. [CrossRef]

5. Berlowska, J.; Binczarski, M.; Dziugan, P.; Wilkowska, A.; Kregiel, D.; Witonska, I. Chapter 13-Sugar beet pulp as a source of valuable biotechnological products. In Advances in Biotechnology for Food Industry, Handbook of Food Bioengineering; Holban, A.M., Grumezescu, A.M., Eds.; Academic Press: London, UK, 2018; pp. 359-392. [CrossRef]

6. Murphy, J.D.; Power, N.M. How can we improve the energy balance of ethanol production from wheat? Fuel 2008, 87, 1799-1806. [CrossRef]

7. Wirth, R.; Kovacs, E.; Maroti, G.; Bagi, Z.; Rakhely, G.; Kovacs, K.L. Characterization of a biogas-producing microbial community by short-read next generation DNA sequencing. Biotechnol. Biofuels. 2012, 5, 41-57. [CrossRef]

8. Li, Y.F.; Chen, P.H.; Yu, Z. Spatial and temporal variations of microbial community in a mixed plug-flow loop reactor fed with dairy manure. J. Microb. Biotechnol. 2014, 7, 332-346. [CrossRef]

9. Ziganshina, E.E.; Ibragimov, E.M.; Vankov, P.Y.; Miluykov, V.A.; Ziganshin, A.M. Comparison of anaerobic digestion strategies of nitrogen-rich substrates: Performance of anaerobic reactors and microbial community diversity. Waste Manag. 2017, 59, 160-171. [CrossRef]

10. Ziganshin, A.M.; Wintsche, B.; Seifert, J.; Carstensen, M.; Born, J.; Kleinsteuber, S. Spatial separation of metabolic stages in a tube anaerobic baffled reactor: Reactor performance and microbial community dynamics. Appl. Microbiol. Biotechnol. 2019, 103, 3915-3929. [CrossRef]

11. Yang, Y.; Zhang, Y.; Li, Z.; Zhao, Z.; Quan, X.; Zhao, Z. Adding granular activated carbon into anaerobic sludge digestion to promote methane production and sludge decomposition. J. Clean. Prod. 2017, 149, 1101-1108. [CrossRef]

12. Capson-Tojo, G.; Moscoviz, R.; Ruiz, D.; Santa-Catalina, G.; Trably, E.; Rouez, M.; Crest, M.; Steyer, J.P.; Bernet, N.; Delgenes, J.P.; et al. Addition of granular activated carbon and trace elements to favor volatile fatty acid consumption during anaerobic digestion of food waste. Bioresour. Technol. 2018, 260, 157-168. [CrossRef]

13. Peng, H.; Zhang, Y.; Tan, D.; Zhao, Z.; Zhao, H.; Quan, X. Roles of magnetite and granular activated carbon in improvement of anaerobic sludge digestion. Bioresour. Technol. 2018, 249, 666-672. [CrossRef] [PubMed]

14. Jang, H.M.; Choi, Y.K.; Kan, E. Effects of dairy manure-derived biochar on psychrophilic, mesophilic and thermophilic anaerobic digestions of dairy manure. Bioresour. Technol. 2018, 250, 927-931. [CrossRef] [PubMed]

15. Wambugu, C.W.; Rene, E.R.; Vossenberg, J.; Dupont, C.; Hullebusch, E.D. Role of biochar in anaerobic digestion based biorefinery for food waste. Front. Energy Res. 2019, 7, 14. [CrossRef]

16. Wang, T.; Zhang, D.; Dai, L.; Dong, B.; Dai, X. Magnetite triggering enhanced direct interspecies electron transfer: A scavenger for the blockage of electron transfer in anaerobic digestion of high-solids sewage sludge. Environ. Sci. Technol. 2018, 52, 7160-7169. [CrossRef] [PubMed]

17. Marsh, H.; Reinoso, F.R. Activated Carbon, 1st ed.; Elsevier Science: London, UK, 2006; pp. 1-554. [CrossRef] 
18. Cha, J.S.; Park, S.H.; Jung, S.C.; Ryu, C.; Jeon, J.K.; Shin, M.C.; Park, Y.K. Production and utilization of biochar: A review. J. Ind. Eng. Chem. 2016, 40, 1-15. [CrossRef]

19. Chen, S.; Rotaru, A.E.; Shrestha, P.M.; Malvankar, N.S.; Liu, F.; Fan, W.; Nevin, K.P.; Lovley, D.R. Promoting interspecies electron transfer with biochar. Sci. Rep. 2014, 4, 5019. [CrossRef] [PubMed]

20. Yao, D.; Wang, J.; Chen, T.; Tan, J.; Wang, G. Methanogenic and carbon sequestration process facilitated by goethite and hematite in the presence of dissimilatory iron-reducing bacteria. Fresen. Environ. Bull. 2016, 25, 1883-1891.

21. Ziganshina, E.E.; Belostotskiy, D.E.; Shushlyaev, R.V.; Miluykov, V.A.; Vankov, P.Y.; Ziganshin, A.M. Microbial community diversity in anaerobic reactors digesting turkey, chicken, and swine wastes. J. Microbiol. Biotechnol. 2014, 24, 1464-1472. [CrossRef] [PubMed]

22. Mohammed, W.S.; Ziganshina, E.E.; Shagimardanova, E.I.; Gogoleva, N.E.; Ziganshin, A.M. Comparison of intestinal bacterial and fungal communities across various xylophagous beetle larvae (Coleoptera: Cerambycidae). Sci. Rep. 2018, 8, 10073. [CrossRef]

23. Ziganshina, E.E.; Mohammed, W.S.; Shagimardanova, E.I.; Vankov, P.Y.; Gogoleva, N.E.; Ziganshin, A.M. Fungal, bacterial, and archaeal diversity in the digestive tract of several beetle larvae (Coleoptera). Biomed Res. Int. 2018, 2018, 6765438. [CrossRef]

24. Caporaso, J.G.; Kuczynski, J.; Stombaugh, J.; Bittinger, K.; Bushman, F.D.; Costello, E.K.; Fierer, N.; Pena, A.G.; Goodrich, J.K.; Gordon, J.I. QIIME allows analysis of high-throughput community sequencing data. Nat. Methods 2010, 7, 335-336. [CrossRef] [PubMed]

25. Nierychlo, M.; Andersen, K.S.; Xu, Y.; Green, N.; Jiang, C.; Albertsen, M.; Dueholm, M.S.; Nielsen, P.H. MiDAS 3: An ecosystem-specific reference database, taxonomy and knowledge platform for activated sludge and anaerobic digesters reveals species-level microbiome composition of activated sludge. Water Res. 2020, 182, 115955. [CrossRef] [PubMed]

26. Miroshnichenko, I.; Lindner, J.; Lemmer, A.; Oechsner, H.; Vasilenko, I. Anaerobic digestion of sugar beet pulp in Russia. Landtechnik 2016, 71, 175-185. [CrossRef]

27. Gerardi, M.H. The Microbiology of Anaerobic Digesters, 1st ed.; John Wiley \& Sons: Hoboken, NJ, USA, 2003; pp. 1-192. [CrossRef]

28. Demirel, B.; Scherer, P. The roles of acetotrophic and hydrogenotrophic methanogens during anaerobic conversion of biomass to methane: A review. Rev. Environ. Sci. Biotechnol. 2008, 7, 173-190. [CrossRef]

29. Fagbohungbe, M.O.; Herbert, B.M.J.; Hurst, L.; Ibeto, C.N.; Li, H.; Usmani, S.Q.; Semple, K.T. The challenges of anaerobic digestion and the role of biochar in optimizing anaerobic digestion. Waste Manag. 2017, 61, 236-249. [CrossRef]

30. Dang, Y.; Holmes, D.E.; Zhao, Z.; Woodard, T.L.; Zhang, Y.; Sun, D.; Wang, L.-Y.; Nevin, K.P.; Lovley, D.R. Enhancing anaerobic digestion of complex organic waste with carbon-based conductive materials. Bioresour. Technol. 2016, 220, 516-522. [CrossRef] [PubMed]

31. Lovley, D.R. Syntrophy goes electric: Direct interspecies electron transfer. Annu. Rev. Microbiol. 2017, 71, 643-664. [CrossRef] [PubMed]

32. Barua, S.; Zakaria, B.S.; Lin, L.; Dhar, B.R. Magnetite doped granular activated carbon as an additive for high-performance anaerobic digestion. Mater. Sci. Energy Technol. 2019, 2, 377-384. [CrossRef]

33. Bernard, K.A.; Wiebe, D.; Burdz, T.; Reimer, A.; Ng, B.; Singh, C.; Schindle, S.; Pacheco, A.L. Assignment of Brevibacterium stationis (ZoBell and Upham 1944) Breed 1953 to the genus Corynebacterium, as Corynebacterium stationis comb. nov., and emended description of the genus Corynebacterium to include isolates that can alkalinize citrate. Int. J. Syst. Evol. Microbiol. 2010, 60, 874-879. [CrossRef]

34. Grabowski, A.; Tindall, B.J.; Bardin, V.; Blanchet, D.; Jeanthon, C. Petrimonas sulfuriphila gen. nov., sp. nov., a mesophilic fermentative bacterium isolated from a biodegraded oil reservoir. Int. J. Syst. Evol. Microbiol. 2005, 55, 1113-1121. [CrossRef]

35. Kröber, M.; Bekel, T.; Diaz, N.N.; Goesmann, A.; Jaenicke, S.; Krause, L.; Miller, D.; Runte, K.J.; Viehöver, P.; Pühler, A.; et al. Phylogenetic characterization of a biogas plant microbial community integrating clone library 16S-rRNA sequences and metagenome sequence data obtained by 454-pyrosequencing. J. Biotechnol. 2009, 142, 38-49. [CrossRef] [PubMed]

36. Weiss, S.; Zankel, A.; Lebuhn, M.; Petrak, S.; Somitsch, W.; Guebitz, G.M. Investigation of microorganisms colonising activated zeolites during anaerobic biogas production from grass silage. Bioresour. Technol. 2011, 102, 4353-4359. [CrossRef] [PubMed] 
37. Zhang, K.; Song, L.; Dong, X. Proteiniclasticum ruminis gen. nov., sp. nov., a strictly anaerobic proteolytic bacterium isolated from yak rumen. Int. J. Syst. Evol. Microbiol. 2010, 60, 2221-2225. [CrossRef] [PubMed]

38. Breitenstein, A.; Wiegel, J.; Haertig, C.; Weiss, N.; Andreesen, J.R.; Lechner, U. Reclassification of Clostridium hydroxybenzoicum as Sedimentibacter hydroxybenzoicus gen. nov., comb. nov., and description of Sedimentibacter saalensis sp. nov. Int. J. Syst. Evol. Microbiol. 2002, 52, 801-807. [CrossRef]

39. Imachi, H.; Sakai, S.; Kubota, T.; Miyazaki, M.; Saito, Y.; Takai, K. Sedimentibacter acidaminivorans sp. nov., an anaerobic, amino-acid-utilizing bacterium isolated from marine subsurface sediment. Int. J. Syst. Evol. Microbiol. 2016, 66, 1293-1300. [CrossRef]

40. Chung, K.T. Inhibitory effects of $\mathrm{H}_{2}$ on growth of Clostridium cellobioparum. Appl. Environ. Microbiol. 1976, 31 , 342-348. [CrossRef]

41. Lee, J.; Koo, T.; Yulisa, A.; Hwang, S. Magnetite as an enhancer in methanogenic degradation of volatile fatty acids under ammonia-stressed condition. J. Environ. Manag. 2019, 241, 418-426. [CrossRef]

42. Roy, F.; Samain, E.; Dubourguier, H.C.; Albagnac, G. Synthrophomonas sapovorans sp. nov., a new obligately proton reducing anaerobe oxidizing saturated and unsaturated long chain fatty acids. Arch. Microbiol. 1986, 145, 142-147. [CrossRef]

43. McInerney, M.J.; Bryant, M.P.; Hespell, R.B.; Costerton, J.W. Syntrophomonas wolfei gen. nov. sp. nov., an anaerobic, syntrophic, fatty acid-oxidizing bacterium. Appl. Environ. Microbiol. 1981, 41, 1029-1039. [CrossRef]

44. Li, H.; Chang, J.; Liu, P.; Fu, L.; Ding, D.; Lu, Y. Direct interspecies electron transfer accelerates syntrophic oxidation of butyrate in paddy soil enrichments. Environ. Microbiol. 2015, 17, 1533-1547. [CrossRef]

45. Zhang, J.; $\mathrm{Lu}, \mathrm{Y}$. Conductive $\mathrm{Fe}_{3} \mathrm{O}_{4}$ nanoparticles accelerate syntrophic methane production from butyrate oxidation in two different lake sediments. Front. Microbiol. 2016, 7, 1316. [CrossRef]

46. Salvador, A.F.; Martins, G.; Mellefranco, M.; Serpa, R.; Ajm, S.; Cavaleiro, A.J.; Pereira, M.A.; Alves, M.M. Carbon nanotubes accelerate methane production in pure cultures of methanogens and in a syntrophic coculture. Environ. Microbiol. 2017, 19, 2727-2739. [CrossRef] [PubMed]

47. Sowers, K.R.; Baron, S.F.; Ferry, J.G. Methanosarcina acetivorans sp. nov., an acetotrophic methane-producing bacterium isolated from marine sediments. Appl. Environ. Microbiol. 1984, 47, 971-978. [CrossRef] [PubMed]

48. Ganzert, L.; Schirmack, J.; Alawi, M.; Mangelsdorf, K.; Sand, W.; Hillebrand-Voiculescu, A.; Wagner, D. Methanosarcina spelaei sp. nov., a methanogenic archaeon isolated from a floating biofilm of a subsurface sulphurous lake. Int. J. Syst. Evol. Microbiol. 2014, 64, 3478-3484. [CrossRef]

49. Dianou, D.; Miyaki, T.; Asakawa, S.; Morii, H.; Nagaoka, K.; Oyaizu, H.; Matsumoto, S. Methanoculleus chikugoensis sp. nov., a novel methanogenic archaeon isolated from paddy field soil in Japan, and DNA-DNA hybridization among Methanoculleus species. Int. J. Syst. Evol. Microbiol. 2001, 51, 1663-1669. [CrossRef] [PubMed]

50. Patel, G.B.; Sprott, G.D. Methanosaeta concilii gen. nov., sp. nov. Methanothrix concilii and Methanosaeta thermoacetophila nom. rev., comb. nov. Int. J. Syst. Evol. Microbiol. 1990, 40, 79-82. [CrossRef]

51. Kröninger, L.; Gottschling, J.; Deppenmeier, U. Growth characteristics of Methanomassiliicoccus luminyensis and expression of methyltransferase encoding genes. Archaeans 2017, 2017, 2756573. [CrossRef]

52. Rotaru, A.E.; Shrestha, P.M.; Liu, F.; Shrestha, M.; Shrestha, D.; Embree, M.; Zengler, K.; Wardman, K.; Nevin, K.P.; Lovley, D.R. A new model for electron flow during anaerobic digestion: Direct interspecies electron transfer to Methanosaeta for the reduction of carbon dioxide to methane. Energy Environ. Sci. 2014, 7, 408-415. [CrossRef]

53. Rotaru, A.E.; Shrestha, P.M.; Liu, F.; Markovaite, B.; Chen, S.; Nevin, K.P.; Lovley, D.R. Direct interspecies electron transfer between Geobacter metallireducens and Methanosarcina barkeri. Appl. Environ. Microbiol. 2014, 80, 4599-4605. [CrossRef]

(C) 2020 by the authors. Licensee MDPI, Basel, Switzerland. This article is an open access article distributed under the terms and conditions of the Creative Commons Attribution (CC BY) license (http://creativecommons.org/licenses/by/4.0/). 